\title{
A PSYCHOLOGICAL APPROACH TO PROCEDURAL REFORM
}

\section{HENRY H. FOWLER $\dagger$}

A HISTORY and literature of procedural and pleading reform for the previous one hundred and thirty years leaves a reader shaken in his estimate of human institutions and puzzled no little at the utter unpredictability of human behavior. He reads with pleasure the logical and practical suggestions of scholarly reformers, recognized authorities in the field, and is confident that adoption of these reforms will oil up the procedural machinery of justice to the highest point of efficiency and that this adoption is only a question of time. His disappointment is considerable when he learns that some of these reforms have never been adopted; ${ }^{1}$ and that some have been duly inaugurated only to have the machine jolt just as badly in the same spots. ${ }^{2}$ Just before abandoning the account in disgust with law and lawyers and legal institutions, he is completely baffled to find that others of these suggestions have not only been adopted but have actually remedied the defect aimed at and that still others have paved the way for later changes which accomplished the desired result.

A partial solution of this enigma can be reached by confining ourselves to the man-in-the-street brand of psychology and setting forth the truisms that everyone recognizes either in overt or subconscious thought. ${ }^{3}$ These it is our purpose to state, not as original discoveries, but as factors the importance of which merits emphasis.

In attacking the problem from this angle, the first query is the natural one: why all this agitation about procedural reform? One wonders why the translation of definite substantive law into judicial decisions which coincide with current ideas of justice should involve so many procedural difficulties; why the rules of procedure need a constant revision; ${ }^{4}$ why they constantly tighten and become harsh in their applica-

†Member of Virginia Bar. Sterling Fellow, Yale School of Law, 1932-1933.

1. See Clark, Code Pleadivg (1928) 35, 36 for a list of the suggested pleading and practice reforms of a major character.

2. Cf. Sims, The Problem of Reforming Procedure (1911) 21 YaLE L. J. 215. This account of some present day procedural problems in relation to previous efforts at solution reveals the vitality of these "evils" in spite of repeated efforts to reform.

3. An examination from the psychological viewpoint has the virtue of being in keeping with the modern tendency to appreciate more fully the polarity between human reasoning and human conduct.

4. Clark, op. cit. supra note 1, at 32 . Commenting on future pleading reform, the author says:

"The ministers of justice must be eternally on the job of keeping their tools keen and bright. It is not a misfortune for a code of procedure to require revision; it is its nature." 
tion, requiring tremendous efforts to renew their liberality and flexibility.

In its inherent nature our judicial procedure involves these difficulties. The system sets up bodies of rules to secure a precision, uniformity and certainty in the application of substantive law as well as an orderly dispatch of business with a saving of time and a maintenance of dignity. ${ }^{5}$ Paradoxically there is a desire that these rules be enforced, but only so long as that enforcement does not limit unduly the operation of an ideal judicial administration. There is a desire that procedure be the "handmaid rather than the mistress of justice." "To fulfil this function properly, procedure must not demand a complete adherence to its rules. There must be an opportunity to allow judicial discretion to pass over variations from the procedural standards or to set up new standards as particular situations arise. Since rules of procedure are of indifference to suitors, except so far as they allow a decision on the merits, no harm results from this flexibility and liberality. ${ }^{7}$ Yet our judicial system does not allow for this paradox in its "fundamental major premise", the doctrine of stare decisis.

Failing to recognize the difference between rules of procedure and substantive law in relation to the vested rights of the parties, the common law judge endeavored to follow precedent in both fields alike. Rules of procedure became binding when announced, and all but a furtive elasticity was destroyed. Cutting off the field of free decision in procedure through stare decisis has made judicial adaptation philosophically impossible. ${ }^{8}$

Breadth of vision in rule enforcement is inhibited by this effort to obey or compel obedience to rules. The repetition of the act of obedience or of the act of compelling obedience thoroughly moulds the ideation of bench and bar, until procedure for them becomes only rules and enforcement of rules; the reason for the rules and the ultimate objective of the system disappear. Repeated situations for interpretation serve to focus a renewed emphasis upon the rule with each interpretation foreshortening the perspective. Judges lay down interpretations. By stare decisis they become part of the rules. Later judges and lawyers respond to comparable stimuli in comparable fact situations to interpret the interpretations. The incentive to obey causes these interpretations to be repeated, and repetition makes them automatic; automaticity encourages a blind response to stimuli; the blind response gives harsh rigidity.

By legislative pronouncement a new set of rules is provided to relieve

5. Pound, Some Principles of Procedural Reform (1909) 4 ILx. L. REv. 388.

6. Per Collins, M. R. in Re Coles, [1907] 1 K. B. 4.

7. Sunderland, The Machinery of Procedural Reform (1924) 22 Micr. L. REv. 293, 296.

8. Id. at $296,297$. 
the situation. In interpreting the new rules, one refers to interpretations of the old rule through stare decisis, thereby reviving the old mistakes and conceptions which the new rule aimed to destroy. The old habit responses with their accompanying ideation return a new rigidity of automatic application. Perhaps a new set of interpretations are set up. Soon another change is necessary.

A further explanation of the necessity for this perpetual change in procedure lies in the historical background of Anglo-American law. The earliest systems of organized courts and trial by jury was only one step removed from the earlier rough form of justice, commonly called trial by combat, and necessarily retained many of the latter's traditions. ${ }^{9}$ It was a contest between lawyers, with each party endeavoring to develop the single material matter of issue, whether of law or fact, which was most likely to result in a favorable decision by the judge or jury." Procedural rules were actually rules of combat, administered by the judge, which regulated the conduct of the battle. This attitude prompted a rigid, uniform application. No umpire could relax or discard a particular rule of combat. The rule had to be applied in the same manner in which it had been applied in previous contests. If, on the objection of the other party, the court decided that the procedure or the mode of combat had not been proper, a retrial or loss of the case might be involved, regardless of obvious merits, because of this Anglo-Saxon desire for a fair fight. The effects of considering a trial as a combat rather than an investigation placed a tremendous emphasis on the procedural aspects of judicial decision.

Another great characteristic of the earlier common law, the forms of action, contributed even more to a procedural conception of justice. In order to sue, the litigant at common law had to secure a writ. The rigid formalism of the age soon required the issuance of writs to be limited to cases where precedents existed, ${ }^{11}$ and the new cases were taken care of by new writs issued by the King. Finally formalism coupled with political influences restricted the framing of new writs to those consented to by a council or parliament in the form of a legislative pronouncement, ${ }^{12}$ whereupon the system settled down by the middle of the Thirteenth Century into one characterized by hard and fast forms of action. The last gasp of Thirteenth Century rationalism to loosen the machinery was the statute of Westminster which directed the clerks of chancery to issue new writs in like cases. But because of the long estab-

9. Cf. Arnold, Trial by Combat and the New Deal (1934) 47 HaRv. L. Rev. 913.

10. 3 Holdsworte, A History of English LaW (3d ed. 1922-26) 639-656; 2 Selict Essays in Anglo-Amierican Legal History (1908) 614.

11. CIARK, op. cit. supra note 1, at 11, 12 .

12. Hepburn, The Developatent of Code Pleading (1877) 35. 
lished habit of viewing the law in terms of concrete forms of action, even this statute failed to give the procedural flexibility needed for the translation of a growing substantive law.

The common law thus remained limited in its relief to the arbitrary units comprising the forms of action. It was therefore natural, habitual and traditional that legal thinking should place the major emphasis always on the formal processes rather than on the spiritual substance. This heritage added its force to the influences that made Anglo-American lawyers peculiarly conscious of procedure by force of pragmatic necessity.

In the meantime, political and economic changes were creating a new wealth of clashing social relationships that demanded judicial determination. The judges tried to relieve the rigid formulary system by fictions and a resort to equity. ${ }^{13}$ These new devices provided only a partial escape from the procedural consciousness of the system, because they sufficed merely to give a remedy where none was available rather than to provide a new method of achieving an old remedy. In other words, these devices produced new substantive law instead of new methods of procedure. It is true that procedure in equity grew to be of a character different from procedure at law. However, the litigant had no choice of procedural methods; he could resort to equity only when the technical rules of substantive law did not offer a remedy.

And so due to its inherent nature and to historical conceptions of mode of trial and basis of remedy, preserved by a conservatism of the profession through five centuries, the Anglo-American procedural system reached the social breaking point early in the Nineteenth Century. The movement then, initiated by legislative power, to synchronize a procedure that by nature and tradition constantly tends to become rigid and formal with a substantive law that constantly develops, requiring flexible means of expression, found it necessary to change the whole tradition and thought of bench and bar.

Reconciled to these factors which militate against permanent procedural reform, it becomes important to develop a technique for conducting constant reform with a minimum of effort and a maximum of success. In order to illustrate the probable psychological principles involved, short case studies are advanced under the headings of The English Reform, The New York Reform, and A Virginia Reform. The points of psychological emphasis will be only implied, leaving the reader to subject the accounts to his own psychological inferences.

\section{The English Reform}

The helpful effects of the Statute of Westminster II in 1285 soon

13. Id at 24 . 
were choked off in the archaic formalism of the age. ${ }^{14}$ Oliver Cromwell and the Puritans made ominous threats of a wholesale reform, but no real action was taken. ${ }^{15}$ Sir Matthew Hale complained a little later that pleading had degenerated from its true rise and end. ${ }^{16}$ Yet during these years there was a growing lay dissatisfaction produced by disgruntled and injured parties who were refused what they deemed justice, because of these technicalities of the law and lawyers.

Coincident with the American Revolution, one Jeremy Bentham opened a vigorous public campaign for reform by an attack on Blackstone's laudation of the common law system. ${ }^{17}$ Opposed by a chorus of professional praise of the existing system, he remained a solitary symbol of the discontent until joined by the lay press. ${ }^{18}$ The press took up the cudgels for reform and became the leader of the British revolt, forming and crystallizing public opinion for some fifty or sixty years. The public was educated so intensively by the press that it was asserted: "The allimportant subject of judicial reform has of late years, happily occupied the undivided attention of thinking men in every part of the country." This exceptional campaign of public propaganda bitterly criticised the legal profession as being responsible for the maintenance of the errors disclosed.

The active campaign inaugurated by the Edinburgh Review in 1802 had gathered enough force by 1828 to induce Parliament to appoint a series of commissions to examine the law of procedure and to suggest changes. This first step was cautious and resulted in the Hilary Rules of $1834,{ }^{19}$ which did little to change the situation.

In 1828 the bar began an active counter movement to oppose this threatened change of the system that would disturb the vested interests of the existing members of the profession. Through their own publications lawyers fought the course of reform viciously at first and then with

14. CIARK, op. cit. supra note 1 , at 12 .

15. HEPBURN, op. cit. supra note 12 , at 69 .

16. Hale, History of Conarion law (1820) 212.

17. Benthadr, A Fragment on Governarent (1776).

18. An excellent and scholarly account of the English reform is contained in an article by Professor Sunderland. It is the basis largely of the present sketch. See Sunderland, The English Struggle for Reform (1926) 39 Harv. L. Rev. 725. The lay press prominent in the early stages of the reform included the Edinburgh Review, the Westminster Review, London Spectator, Saturday Review and the London Times.

19. 3 and 4 Wr. IV, c. 24 (1833). Cf. CLarK, op. cit. supra note 1, at 15: "The special accomplishment of these rules was to limit the scope of the general issue in the formed actions and to force the defendant to set up affirmatively all matters other than a denial of the breach of duty or wrongful act of the defendant." These changes were drawn by Stephen, the exponent of special pleading, and led to the old system of special allegations, which some think was a "disastrous mistake." See HEPBURN, op. cit. supra note 12, at 76 et seq. 
slowly abating force and zeal. As long as this professional opposition was heavy, the attempts at reform were gradual; there were tangible results in a number of small bills and amendments "which not only familiarized the profession with new ideas during the slow course of the debates, but introduced actual changes at so moderate a rate that the bar became reconciled to one reform before the next was forced upon it."20 A constantly increasing public pressure, contenting itself with small but decisive victories finally convinced the bar that changes were inevitable and by 1850 brought the acceptance of the alternative desire to lead the course of the reform. ${ }^{21}$

This warfare of nearly fifty years served to provide a wide public and professional hearing, educating both public and bar to a full realization and understanding of the problems. The issues were fought out before action, with mutual understanding as the keynote. The result was that the rank and file of the profession, finally enlisted to the cause of the reformers, presented the conservative views that ended to keep proceedings on solid ground and the technical skill necessary to design the proper remedy.

The actual reformatory legislation on this basis was begun more vigorously than in 1832 . The movement was still cautious as the reformers slowly felt their way. ${ }^{22}$ The enactment of the leading reformatory statutes which began in 1852, extended through twenty years. First came a series of statutes establishing a reformed system of pleading at law, known as the "Common Law Procedure Acts", which extended in course of enactment through eight years from $1852 .{ }^{23}$ These statutes were not of sudden growth but were based on reports of law commissioners who began work in 1831 . They were, however, only a temporary expedient to pave the way for more extensive and radical legislation. Corresponding acts were then passed for the regulation of equity procedure. The similarity between many of the provisions of these acts and those of the Common Law Procedure Acts tended to break the way for attempted fusion between law and equity. ${ }^{24}$ After a period of familiarization with these limited steps toward reform, the great step was taken in the Judicature Act of $1873,{ }^{25}$ which swept away the English

20. Sunderland, supra note 18 , at 736 .

21. Id. at 737 .

22. Cf. HEPBURN, op. cit. supra note 12, at 176 . In footnote 1, the author comments on an article in 12 SOLTCTTORs' JOURNAL AND REPORTER 643 saying: "but at the same time it is declared to be unnecessary to make 'any sudden or violent change' in order to introduce these radical alterations. 'New common law procedure acts', says the writer, 'might be passed modifying the procedure by degrees'."

23. HEPBURN, op. cit. supra note 12 , at 177 .

24. Id. at $180,181$.

25. 37 VICT. c. 66 (1873) "Supreme Court of Judicature Acts 1873." 
system of common law pleading even more completely than did the American codes. A recital of the cures which these series of reforms provided for the old evils ${ }^{26}$ is not necessary to this discussion. It should be noted that the Acts do not regulate the details of practice, but leave them to the court, which makes and changes the rules of practice, ${ }^{27}$ giving a flexible system subject to the revision and improvement that circumstances demand. ${ }^{28}$

These changes could not forever cure all faults, but a general statement is justified that the English reform culminating in 1873 is accepted in the minds of the English bar and public and the majority of American observers as one of the most successful efforts of its kind in history. ${ }^{29}$

\section{The New York Reform}

The English common law system transplanted in America produced the same evils of procedure with attendant dissatisfaction. This unrest was most pronounced in New York, where legal procedure was modelled closely after the English system. ${ }^{30}$ One historian ${ }^{31}$ places the beginning of the agitation sometime after 1826. Little is known of its progress, and it is presumed that it received no such airing before public and bar as was the case in England. The first outward manifestation was a bill introduced in 1842 in the New York legislature "for the more simple and speedy administration of justice in civil cases in the courts of common law." Four years later the demand for radical reform produced through the new Constitution a single court having jurisdiction of both law and equity. There was a provision that the legislature should appoint three commissioners whose duty it should be to revise, reform and simplify procedure and report back their findings. The legislature prescribed the nature of their duties explicitly: "to provide for the abolition of the present forms of action and pleadings in cases at common law."

These suggestions were of the most radical nature, imposing a task far beyond the boldest designs of the English reformers, who at that time had been at their work for almost fifty years. The deep-rooted system

26. HEPBURN, op. cit. supra note 12 , at 182 et seq.

27. Rosenbaum, The Rule Maknjg Authority in the English Supreare Court (1917).

28. For a collection of authorities on the question of the wisdom of the rule-making power see CLARK, op. cit. supra note 1 , at 33, n. 103.

29. For a list of references see CLARK, op. cit. supra note 1, at 17, n. 44 .

30. HEPBURN, op. cit. supra note 12, at 80 ; cf. remarks of David Dudley Field (1891) 25 Ars. Law REv. 515, 519.

31. The history of the cause of the New York reform is based largely upon material in Professor Hepburn's thorough account, which is a valuable collection of data on the whole development of code pleading. 
of centuries was to be changed completely in a day. The large majority of lawyers, true to the conservative tenets of their profession, were opposed to a change. Hepburn expressed the problem of the commissioners as follows:

"The prejudices of thousands of practitioners must be disregarded and the habits of their daily lives reversed; the active opposition of many able men recognized as profoundly learned in the law must be overborne; a community accustomed, especially in such matters, to be led by their lawyers must be assured of safety in turning aside to follow a few reformers. In the face of such obstacles the three commissioners were asked to design and construct a new system which they could recommend as capable of doing all the work of the old, and doing it better."32

One member resigned rather than carry out the command. The other two opposed the tenor of the more radical changes, but Mr. David Dudley Field, who proved to be the moving spirit, was in complete sympathy with the movement. The commission was appointed in April, 1847, reorganized in September. Five months later they reported the draft of an act in fifteen chapters, with nearly four hundred annotated sections, "to simplify and abridge the practice, pleadings, and proceedings of the court of this state." This code was passed with some amendments on April 12, 1848, and became operative on July 1st.

During the next twenty-five years the code underwent five hundred and forty-one legislative changes, but retained its more important and substantial features. It received extended judicial discussion, interpretation and criticism, but was believed by its friends to be well on the way to become established and understood. Hepburn says:

"Up to this point [1876] the history of the New York Code is significant as being that of many codes, and not of the New York Code alone; but from this on the story is rather a prophecy of what may happen in other codes if the noble art of statutory revision goes mad." 33

A new commission for revision was appointed in 1870. Six years later a bill for a new code of procedure to contain fourteen hundred and ninety-six sections was submitted to be enacted, first in 1876 and again in 1877, under the name, "Code of Civil Procedure."

It contained the fundamentals of the former code, but showed a vast increase in bulk, running its requirements into the most minute and trivial details. ${ }^{34}$ It smothered its principles in details obscuring the ideals of the original framers and destroying their accomplishment. ${ }^{35}$ After 1880 the code was constantly amended and supplemented until it

32. HEPBURN, op. cit. supra note 12 , at 83 .

33. Id. at 129, n. 2 .

34. Id. at 130 .

35. Id. at 131. 
came to number in excess of thirty-four hundred sections, as against three hundred and ninety-one of the Field code ${ }^{36}$ occupying with its annotations "three gigantic volumes which appall the legal mind, and fire the lay mind with awe and dismay."37

This "Brobdignagian conglomeration of heterogeneous rules of law and practice" was supposed to be a reform. It produced such dissatisfaction that in 1895 the legislature appointed a commission to report in what respects a revision, condensation or simplification could be secured. An investigation was made of the views of practicing lawyers. Although there was a variance in answer and suggestion, the prevailing tone seemed to be in favor of a conservative reform upon a historical and comparative basis. The movement went forward at a slower tempo. In 1904 a Board of Statutory Consolidation composed of five members was created to consolidate the laws and revise practice. The Consolidated Laws of 1909 was the first result. In 1912 the Board undertook to present a detailed plan for the revision of practice. The report was made in 1915, consisting of a short practice act of twenty-one sections, and four hundred and one rules of court. It was referred to a Joint Legislative Committee, who reported in 1919, rejecting the main feature of the Board Report, which was the short act with broad rulemaking power in the courts. They offered a Civil Practice Act, which went into effect in 1921. This Act is said to be in many ways an improvement over the former code, but the process of amendment has already begun, and unfortunately may be expected to continue. ${ }^{38}$

The history of this reform bespeaks the difficulty involved. Nevertheless, the reform of 1850 served at least to develop new procedural attitudes by the bar, which have been manifest in repeated efforts to crystallize advanced ideas into workable form. Its spiritual values in that particular cannot be discounted and have made possible the present day progress along procedural lines. But the reform as a whole stands as an example of hardship and failure involved in efforts at procedural improvement. The particular approach used, together with the factors that provoked the most trouble, are worthy of analysis and consideration by those who would avoid them.

\section{A Virginia Reform}

The third case study is much less widely known than the others. Actually, very little source material of a historical or critical nature is available. Tracing of a conscious movement of a militant philosophical conception culminating in a definite reform would not be a realistic

36. Clark, op. cit. supra note 1 , at 25 .

37. See (1896) 53 ALB. L. J. 151.

38. CIARK, op. cit. supra note 1 , at $26,27$. 
presentation of the process by which a minor method of procedure has unobtrusively and gradually developed into a complete system in Virginia, known as the notice of motion procedure.

The history of the reform consists largely of a series of legislative enactments. $^{39}$ Not long after the Jamestown settlement took on the proportions of a colony the need for a summary method, quicker than the cumbersome old common law method, for checking up on the use of public funds by sheriffs prompted an enactment $t^{40}$ that gave the proper state official option to proceed by the ancestor of what is now a notice of motion proceeding, not markedly different from the present form. This device was soon utilized to give quick justice in various situations. ${ }^{41}$ It was extended to a strictly private law atmosphere by making it available to sureties in $1787^{42}$ because it was felt they needed a hasty remedy against a defaulting principal. In 1849 the right to proceed by motion was given to "any person entitled to recover money by action on any contract." ${ }^{243}$ Almost the only inkling that the extension smacked of reform is contained in a report of the revisors. This report mentioned the current procedural reforms in England and New York and spoke with pride: "But in neither country have any pleadings been introduced simpler or shorter than the proceedings in Virginia notice of motion."

There followed a statement of the decision to extend this proceeding to contracts for money, because it had worked satisfactorily in previous instances. One very important device was used which speaks volumes for the psychological acumen of the revisors. The use of the new proceeding was made optional instead of mandatory. Judge Burks, one of the leading spirits of the revision, made the following significant comment before the Virginia Bar Association:

"Out of deference to the views of others, the revisors, while retaining the old mode of procedure, have so enlarged the informal proceeding by motion as to provide, etc. (quoting Sec. 6046) . . . These two changes, it was thought, would give the advocates of code procedure full opportunity to develop the merits of the system, and if they proved to be more satisfactory than the present system the transition could be much easier than by a complete substitution of one for the other at the present time."144

39. For two brief historical expositions, see Clark and Samenow, The Summary Judgment (1929) 38 YaLE L. J. 423. 463; Millar, Three American Ventures in Summary Civil Procedure (1928) 38 YaLE L. J. 193.

40. Acts of 1644-5, 1 VA. Stat. (Hening) 297.

41. Acts of May, 1732, 4 Va. Stat. (Hening) 352. In this Act the statute took its form of a motion to be made after a ten-day notice. Cf. Acts of 1748, 5 VA. STat. (Hening) $\mathbf{5 3 4}$ for extension to action on a failure to pay a forthcoming bond.

42. Acts of 1786,12 VA. Star. (Hening) 268.

43. VA. CODE (1849) 640, c. 16\%, \& 5.

44. Burks, The Code of 1919 (1919) 5 VA. L. REg. (N. S.) 97, 121. 
Moreover, the included cases were of a character calculated to arouse the minimum of dispute and generally did not require a complicated procedure. It was not until 1919 that the proceeding was finally extended to all actions at law. ${ }^{45}$

When a corresponding system was being considered for West Virginia recently, an investigation was made of the effectiveness of the notice of motion procedure in Virginia. ${ }^{46}$ The frequency of use as opposed to the old common law system, the opinions of the bar, and the amount of procedural litigation were the measuring rods employed. The results were convincing as to the relative success of the new system both in terms of popular esteem and theoretical evaluation. Added testimonials are presented by more recent proposals ${ }^{47}$ placed before the Judicial Council of Virginia to extend the system to include proceedings in equity, as well as actions at law.

\section{The Psychological Variables}

The relative failure and success of procedural reform in these three instances reflects a number of causes. It is the present thesis that one of the major causes lies in their psychological basis and execution. What is actually involved in a procedural reform? A group of individuals, in regulating their conduct in certain situations, rely on a pattern of behavior set up by authorized governing bodies and applied by courts to particular instances. The constant attempt to obey or compel obedience to this pattern ingrains it by repetitive action into the habits and customs of this group until the pattern is no longer a mere printed form, but a part of the mental and psychological machinery of those who use it. When a legislature tears the printed pattern out of the statute books and inserts another, the reform is only begun. The substitution of a pattern on the statute books is successful only if it replaces the old one in the minds of those who use the patterns, ${ }^{48}$ resulting

45. VA. CODE (1919) §6046.

46. Report of Committee on Legal Reform of Pleading and Practice (1929) 36 W. VA. L. Q. 1, 67 et seq.

47. (April 30, 1929) 2 VA. Jud. Councr REP., Appendix I. The matter is discussed at length throughout the Judicial Council Report. The Committee on Chancery Reform reported favorably upon the suggestion, but action was deferred to iron out some difficulties of adaptation.

48. Proskauer, A New Professional Psychology Essential for Law Reform (1928) 14 A. B. A. J. 121. "Workable law reform will not be accomplished merely by specific change in statute and rule. It must rest largely on a fundamental change in the group psychology of the legal profession toward its function. . . ."

Cf. Report of Committee on Legal Reform of Pleading and Practice, supra note 46, at 27: "Codes of pleading are like constitutions. The actual rules which they lay down are not as important as the frame of mind of their interpreters." 
in a change in their habits of action and thought. In the field of procedure, at least, one may legislate a dozen times without effectually changing the pattern of human behavior so as to set up a new system of law, for "laws, being formulations of public opinion, cannot exist until public opinion has become fixed and settled and cannot change until a change of public opinion has become complete."49 The translation of a new pattern into the minds of the users may lead to tremendous psychological difficulties. ${ }^{50}$ A complete and emphatic realization that procedural reform necessarily involves this translation of an objective pattern into mental habits and human behavior is the basis of the present approach, an assumed major premise on which the minor phases of development depend.

Of course the problem is fundamental in all human movements involving change; for the static element in the universe always opposes the ever attacking forces of change. But in addition to this generic phase, procedural reform has its own local problem in that it deals with law and lawyers. The conservatism of lawyers is proverbial. Many observers have recognized this factor and expressed opinions regarding its relation to reform. It plays such an important part in the problem that it seems worthy of analysis.

Law in its mechanical function is a government of society by rules. This science is not compatible with change. Rules are set up to be preserved and maintained by lawyers. Men act in reliance upon them. They cannot be changed from day to day. The application of these rules, the task of lawyers on bench and bar, results in an intense desire for a certainty ${ }^{51}$ which is incompatible with the changes that a reform involves. The daily training of the lawyer, the eternal hunt for precedent, the desire for certainty, all give him a trust of the past. ${ }^{52}$ Moreover, the constant association by leaders of the bar with bankers, manufacturers and capitalists, whose system fears changes, is said by some to heighten this conservatism. ${ }^{53}$ It is natural therefore that lawyers should be opposed to change.

This conservatism in its opposition to reform is particularly noticeable

49. Pound, supra note 5 , at 389 .

50. Sunderland, supra note 18, at 745: "But the rank and file are still too heavily loaded with traditional ideas and too much blinded by preconceptions to give the support which is necessary for real progress. Habits of thought determine not only what faces we see but the light in which we see them. In the case of the legal profession the habitual use of a fixed procedure has made the majority of American lawyers utterly incapable of appreciating how absurd are the technicalities which cripple its usefulness."

51. See Frank, LAw AND THE MODERN MIND (1930) for a psychological explanation of this "desire for certainty," and its results in the Anglo-American legal system.

52. Whittier, Notice Pleading (1918) 31 Harv. L. Rev. 501.

53. Ibid. 
where procedural reform is concerned. Cromwell found the opposition to his threatened changes too strong. He said:

"These sons of Zeruiah are yet too strong for us; and we cannot mention the reformation of the law but they presently cry out we design to destroy propriety." 4

Bentham and the English reformers encountered the same opposition. ${ }^{\text {t5 }}$ In New York the opposition of the profession to the reforms was recognized by no less person than David Dudley Field himself. ${ }^{50}$ An observer has very sagely summed up causes of this unfriendly spirit in New York as follows:

". . This unfriendliness was but natural. To ask men who had, at the expense of half a life-time, acquired proficiency in a profession the most difficult, to discard their former learning, and adopt a new system which to them seemed crude and impracticable, was a proposition, not only startling but naturally repulsive ... few men, skilled in the common law and chancery practice, who reach middle life before the introduction of code procedure, ever become expert in the latter, or lose their partiality for the former. This unfriendliness leads the veterans of the bar, upon the introduction of code procedure, to adopt no more of its requirements, nor conform to any more of its rules, than become absolutely necessary; holding on to all the technical niceties, and all the superfluous and redundant verbiage possible to be called into the procedure, under the new system. This spirit was more or less countenanced by the judges in many of the States, when their contempt for the new system was often illdisguised."

This conservatism is not always to be disdained or regretted in consideration of the function of the law to ease and ameliorate the pangs of social change. ${ }^{58}$ But its application to the field of procedure, where changes of method and attitude are necessary to enable the courts to keep apace with inescapable social change, should be constantly dif-

54. HEPBURN, op. cit, supra note 12 , at 69 .

55. Sunderland, supra note 18 , for the details of the opposition. Hepburn says, speaking of the lawyer in connection with procedural reform: "His instinctive position was, as it is and should be, against all changes; and his superstitious disrelish for a change was intensified when the change threatened the common law procedure. In his eyes it was a system to be venerated. It had existed from a time whereof his memory ran not to the contrary. His habit of thought for generations had been, not that common law procedure should be changed to meet new conditions of fact, but that new conditions of fact should be so treated that they would appear to meet the formal requirements of the common law system." See Hepburn, op. cit. supra note 12, at 37, 38 .

56. See Field, Codification in the United States (1889) 1 JuRm. Rev. 18, 20.

57. (1879) 8 CENT. L. J. 411. The same idea is expressed by Professor Sunderland, supra note 7, at 295. He quotes Lord Birkenhead as saying: "Success is in most cases attained only at a mature age, when the mind might be expected to have acquired a suspicion of novelty, and a respect for wont and tradition."

58. Field, supra note 56. 
ferentiated. ${ }^{59}$ It is aided and abetted in procedure particularly by the peculiar monopolistic position of the profession, which gives rise to an inertia that offers no immediate self-interest to undertake reforms nor a mental outlook capable of discovering the necessity for them. ${ }^{60}$

This conservatism coupled with the professional inertia presents an especial handicap to the procedural reformer ${ }^{31}$ which must be overcome before the transmission of the new pattern into resultant mental behavior can occur. The general education of the bar has been suggested as the source of remedy. ${ }^{62}$ This seems fundamental to any continued state of social efficiency. But for particular reforms, there would seem to be necessary an especial, individual campaign of education through some channel close to the bar. The reformer as a preparatory measure should carefully examine the peculiar situation, isolating the particular variables in the equation, and then design the campaign that will account for them. Some of the more usual variables will be suggested.

The initial problem is to ascertain and estimate the opposition. $\mathrm{He}$ should determine whether the resistance to his project is apt to lie in the inertia of the static tendency heretofore referred to, or in an actual repugnance springing from an affirmative attitude or tradition. A distinction may be noted between a general and a specific reform. ${ }^{63} \mathrm{~A}$ general reform is apt to involve an attitude or tradition by reason of its broad scope. If it is possible to accomplish the desired result by confining the changes to small specific areas that will not abruptly cross a fixed general attitude of mind and habit of some concerned group, a minimum of resistance may be encountered. The change in the small area may eat away at the general attitude unobtrusively without having the full force of its spiritual existence to overcome. For example, a reform of pleading so broad as to challenge the attitude of veneration of the common law system was subjected to great resistance in New York in 1850 , whereas a specific change that was disguised as a minor device to mend the main defects was received gladly in Virginia in 1849 .

This in turn points to the problem of whether the mechanical changes of a reform should be accompanied by a philosophical doctrine. Many a valuable reform received a death blow when the reformer called to the fore philosophical and ethical propaganda. This procedure almost inevitably extends the battle line along a larger front until it generates an

59. Sunderland, supra note 7 , at 295 .

60. Sunderland, supra note 18 , at 726 .

61. See Clark, Methods of Procedural Reform (1929) 36 W. VA. L. Q. 106, 107: "Any program of reform of justice which does not face the likelihood of an indifferent, if not hostile legislature, and a bar at least one-third inert and one-third openly antagonistic is not based on the realities of past experience."

62. Sunderland, supra note 18 , at 745 .

63. Taft, The Delays of the Law (1908) 18 Yale L. J. 28, 31, 32. 
opposing philosophy or includes a general attitude in the attack. For example, it is easier to get across a six hour day on a rather matter of fact basis as a helpful industrial change that will provide more jobs and. help both capital and labor, than to philosophize about it as a means of redistribution of wealth or a rearrangement of our industrial structure called for by the principles of a new collectivism. Of course, this general rule may have its exceptions. If one cannot command enough support for the changes to secure their adoption on a matter of fact basis, he may be forced to call philosophy into play to build up a militant emotional support that will spread the gospel. ${ }^{64}$ But if the reform deals with mechanical changes that promote accuracy, conservation of time, effort or money, or if it has certain commonplace values which appeal to the common sense of a large number (as it will have if it is a substantial improvement), then an effort should be made to effect it on those bases alone. To advance broad philosophical or ethical theories of support may be to incur unnecessary risks of resistance, or to lose the specific changes in a mass of generality.

However, a fatal weakness of reformers as a class is to ascribe great ethical values to their pet movements as cogs in a philosophy which has envisioned an ideal far ahead. This tendency to surround their efforts with an aura of grandeur suggests another variable, namely, the personality and public pose of the reformer or reformers. One might venture that the will to reform has a mixed motivation. It includes a desire to make things better merely for the sake of having them better, and also a desire for self-expression through which the reformer may assume some pose before others that gives him pleasure. If all reforms were anonymous, we would probably have fewer of them. Aside from this purely egoistic feeling, there may be the kindred desire to see one's brain child or spiritual penates adopted by other men, because it is one's own. But the more the personal element enters into a reform, the more is it the case of " $m y$ house is better than your house, $m y$ ideas are better than your present ideas, my plan will rescue you from the trouble your stupidity or weakness has created, $I$ am the great leader," and so forth. Let that impression gain even a subconscious hold in the mind of the reformed, and one of two things may happen. The reformed will strike back at the reformer through his reform, proving to themselves and others that it is not so good, and thereby destroying the offensive material evidence of the reformer's indirect but immodest claim to superiority. Humanity is a great leveler. It will follow the one thinking its own

64. The subject of propaganda is of prime importance in the contemporary movements labelled Communism, Fascism, Hitlerism. The machines for philosophical and emotional appeal have become the real factors of might rather than the personalities of rock-bottomed platforms. This touches off the whole subject of public opinion. 
thoughts in its own terms; while the Puritan "holier than thou" is unpopular.

Yet the other and more extraordinary thing may happen. If the reformer is one of those rare persons whom people enjoy glorifying, in whom people have the greatest confidence, or on whose band wagon it is fashionable or advisable to climb, whose magnetism of personality is an asset to any cause, the reform may receive impetus from playing up that personal element. If Robert E. Lee and Stonewall Jackson had become associated with a movement for old age pensions for retired slaves in 1862 Virginia, the movement would have been formidable. Technocra$c y$, on the other hand, suffered because it emanated from a comparatively unknown engineer. Accordingly the reformer or reformers should take careful stock of personality appeal before that element is admitted into the campaign. The support of some venerable old Judge of the Court of Appeals might be enlisted to advantage.

At all costs the use of the reform as a vehicle for personal glorification or publicity while the campaign is on should be avoided. Careful measures should be taken to prevent any jarring of the sensibilities of the reformed by the reformers or well-meaning friends of the press and rostrum. Sometimes the substitution of the word or idea of regulation for the label reform tends to reduce opposition. Lawyers, for example, might be more willing to think themselves and their institutions regulated than reformed.

The attitude of the bench and bar toward procedural legislation should be another primary consideration. A leading inquiry may be the number of minds containing a feeling of grievance against the fault or error to be corrected. $^{65}$ It may be that the discontent or desire for change is so

65. See Cardozo, An Advance in Legal Reform (1923) 30 W. VA. L. Q. 152, 159, 160, where it was said concerning the work of a Reform Commission: "One other thing the Commission can do within the brief term of its existence. It can sound public sentiment and particularly the sentiment of the bar to discover the branches of the law in which the need of the change is greatest."

See Paul, The Judicial Council and the Reform of Judicial Procedure (1925) 5 ORE. L. Rxv. 1 for a general discussion of a practical nature concerning methods of procedural reform to be employed by a body delegated to perform that function.

Cf. (April 30, 1929) 2 VA. JUD. Councer REP. 10 for an interesting commentary in a Judicial Council Discussion:

"The Chairman: Is there any discussion of that motion? I take it that the matters referred to in this report are matters about which the opinion of the bar has been crystallizing, and certainly as to most of them the bar favors the changes suggested.

"It seems to me, however, that as we are to have a meeting at the Hot Springs to which we have invited the bar of the State, the better disposition would be to place the report on file and have it printed and be a matter for the consideration of the bar between now and the Hot Springs meeting and that this body endeavor to dispose of it at the Hot Springs." 
pronounced in an overwhelming number of those affected that the problem is simply one of mechanical change of patterns or a public ritual of adoption. More often it may be that the discontent is confined to a restricted number of the more sensitive and perceiving minds, who have the power and ability to express their feelings in a statute or by formal process of adoption.

If this be the case the transfer of that formal documentary pattern into the habits, acts and ideation of the mass must have a mechanism if substantial success is to be attained without abortive effects. That mechanism may take the form of a long debate which gives those affected a chance to familiarize themselves with the error and the change and to propose compromises or amendments which make it more pleasing to a larger number; it may be a campaign in the publications of the bar or the press; it may be a presentation to bar associations or similar units in order that they may feel that they have a part in the movement; on occasion, it may be the mere stimulus of actual contact with the changes by action in conformance with them. ${ }^{66}$ Some such transmitting mechanism is the sine qua non of a successful procedural reform. ${ }^{67}$

Proceeding from the assumption of reform as a process of transmission and the necessity of provision for a mechanism of transmission, one is confronted with the dual question of the best type of material to be transmitted and the capacity of the mechanism. The very difficulty of breaking down old habits and ideas and replacing them with new ones compels the conclusion that the smaller the portion of this process the procedural reform involves, the greater the likelihood of lasting success. One cannot be too careful not to include many details, which require just as much freight in the transfer process as do the fundamental ideas of the reform. They may overtax the assimilative process. Therefore a statute that embodies the core of the change in definite, concise expressions of policy or method would seem to be preferable to a detailed, complex pattern that may overwork the habit breaking and forming

66. See Book Review (1932) 47 PoL. Scr. Q. 136, 137, in which the methods of the Benthamites are described as follows: "Through the endeavor to overcome similar obstacles, however, the reformers unconsciously worked out a sort of common technique of reform. First appeared the 'agitator', then an organization for extending public interest; propaganda would finally get a proposal before Parliament when after many attempts passage of a measure would probably be accomplished; finally amendments would make necessary a consolidating act. But if the process was long drawn out, the method ultinately called into existence such an extensive body of adherents as to insure success to the legislation."

67. See Sunderland, supra note 7, at 294. He says: "Reforms are not brought about spontaneously. Some agency must propose, formulate and validate them. Back of the reform itself is the means and mechanism by which it must be brought about. The machinery of reform is a subject which has received too little attention." 
apparatus and lose its meaning and appeal by reason of its disseminated and unconcerted attack. ${ }^{83}$ The new frame of mind that will result from the application of a few well chosen policies will reasonably assure the administration of the reform as to the details.

The details of administration of the reform may be left to the discretion of the trial judge. He can decide on each particular set of facts according to his version of the general spirit and method of the reform. Any abuse of discretion revealed in his interpretations may be checked up by the appellate court, dictating its view of policy only when it thinks it necessary to the particular case. If the detail comes up with undue frequency, it may be taken care of legislatively, or by a rulemaking power in the judges or some judicial council. ${ }^{69}$ Since the dangers of judicial abortion are lessened by this channel of reform, ${ }^{70}$ this system seems to fit the psychological setting.

The final phase of the problem in relation to the pyschological premise is a determination of the rate of speed at which the mechanism can be manipulated to secure the proper and lasting result. Two extremes appear as types, namely, a gradual evolution as against an instant revolution. The revolution is the manifestation of a sudden spiritual flare-up that is primarily destructive. A whole mass of habit and mode of thought is thrown overboard in one fell swoop, with little or no replacement at hand. Either replacements come from hastily constructed and untested ideas, ${ }^{71}$ or the revolutionized begin to draw from the old ideation. The old habits creep back in. The old is destroyed regardless of the capacity of the mechanism of change. The forces of habit and reaction revive the old attitudes in new forms. These ill effects of procedural revolution have more than once been emphasized by observers. ${ }^{72}$

68. See (1910) 35 A. B. A. REP. 635. Appendix E. In this report some principles of practice reform of a functional character were outlined. They have some bearing on the psychological process particularly in relation to the question of reform in many minor details.

See Pound, supra note 5, at 403; HEPBURN, op. cit. supra note 12, at 130, 131; (1895) 53 AIB. L. J. 150, 151; (1877) $16 \mathrm{id}$. at 216, 217. Also see the attitude of the revisors in West Virginia as expressed in 36 W. VA. L. Q. 27. They express their desire to effectuate a simple general attitude rather than to legislate a mass of rules. A large group of procedural experts seem to agree that practice legislation of the future should embody general methods, leaving the details of application to the judges. Pound, The Canons of Procedural Reform (1926) 12 A. B. A. J. 541; Sunderland, The Exercise of the Rule-1Laking Power, id. at 548 .

69. See CLARK, op. cit. supra note 1 , at 32,33 and $\mathbf{n} .103$ for a collection of authorities commenting on this feature of a reform program.

70. The hostility of the New York judges to the reform in 1848 is believed to have been one of the prime causes of its failure.

71. Cf. Sims, supra note 2; Paul, supra note 65 .

72. Sunderland, supra note 68 , at 550; (1879) 8 CENT. L. J. 450, 452 . Cf. Pound, supra 
A gradual evolution, on the contrary, accustoms the mind" to the change; it moves along at the same rate that the mechanism of change can break down old attitudes and ideas and build up new ones. The evolving process enables its subjects to discard the old habits that a natural selection no longer deems desirable. By keeping pace with the changing thought, the wisdom and permanence of the reform are likely to be increased.

The failure of the New York procedural reform to fulfill the expectations of its exponents can fairly be attributed to neglect of the psychological considerations set forth above. This fact is manifest in the comments both of practitioners close to the time of the reform and of observers generally. It was a revolutionary outburst which entailed a complete change of the existing pleading system; it was a conscious movement towards an ideal which was based on a philosophical attitude toward pleading as a function; it was a complete overturn. On the other hand, the remarkable measure of success attained in Virginia demonstrates the effectiveness which conscious or unconscious conformity to psychological principles can impart to procedural changes. The Virginia notice of motion represents a system of pleading embodying the ideals of experts and laymen alike, in respect to its simplicity, speed, and freedom from technical delay and miscarriage. The amazing fact about this system is that it has worked, encouraged and commended by both bench and bar, who seem to have kept it surprisingly free from the usual procedural blights.

By making this new system optional, the psychological hurdles were minimized. No opposition complexes were aroused, leading to technical application or abortion of its principles and function. The old system was always available, working as it had previously. The lawyer and judge could weigh the comparative advantages and disadvantages of the two conceptions and have superiority proved in a practical manner. By the optional feature both bench and bar had abundant opportunity to replace gradually the old habits and ideas; the change was a gradual, steady movement which was calculated not to tear out old attitudes, but to give opportunity for the building of a new psychological conception in the minds of those in whom this conception was necessary.

By confining the use of the new system to a small field in its initial stages, and gradually widening its scope to all actions at law, the full measure of psychological effectiveness was achieved. It served to educate the minds of those concerned as to the functions and technique of

note 5, at 508: "From the New York Code of 1848 to the present, the bane of procedural legislation has been hurry. Let us settle the principles carefully and thoroughly." (1926) 6 ORE. L. REv. 17; Beal, Some First Principles and Common Delusions (1925) 9 Const. Rev. 81. 
the new system. They became acquainted with it at first hand on a small scale and could experiment of their own volition until their satisfaction with its utility was assured.

Here is an exemplification of the provision for reform according to the announced philosophy. The conservatism of bench and bar was avoided by the option; an educative mechanism was provided in the use; the material to be transmitted was composed of general principles and attitudes free from detail; the rate of the change of ideas and habits was as speedy as the mechanism permitted. The permanence of the change was assured as far as possible by use of a method that built new attitudes and gave a new emphasis, calculated to avoid a historically inherited procedural consciousness.

In conclusion, the need of a scientific method ${ }^{73}$ and an adequate machinery must be stressed again. The importance of a methodology of procedural reform, conceived on a sound psychological basis, is not fully realized, although it has received enough recognition to justify the assumption of its objective existence. The failure of scholars and reformers properly to explore and exploit the mass psychology at their disposal for attainment of helpful ends ${ }^{74}$ might well be replaced by deliberate strategy.

73. Paul, supra note 65 .

74. Arnold, Law Enforcement (1932) 42 YALE L. J. 1. 